\title{
Un proceso sin sentencia. Acusado y acusadores en la diócesis de Coria en 1591
}

\author{
Angel Rodríguez Sánchez *
}

El legajo 75 del Archivo de la Catedral de Coria ${ }^{1}$ contiene el Edicto y Cartas Generales que promulgó el Obispo de Coria D. Pedro García de Galarza, y la respuesta social que se produjo al interrogatorio que formulaba en el Edicto. Esta documentación, que sirvió para conocer el estado moral de la comunidad cauriense y para preparar los Sínodos cuyos cánones regirian la vida diocesana hasta bien entrado el siglo $x \mid{ }^{2}$, tiene precedentes en otros interrogatorios que también desembocaron en convocatorias sinodales, pero con una finalidad distinta: las encuestas de los Obispos Mendoza y Bobadilla, y Diego de Deza, que precedieron a

* Catedrático de Historia Moderna. Universidad de Salamanca.

- Lo he dado a conocer con anterioridad en Inmoralidad y represión en Coria en el siglo xvi. Historia Moderna. Actas de las II Jornadas de Metodología y Didáctica de la Historia. Cáceres 1983; en Hacerse nadie, Cáceres 1984; y en Moralización y represión en la España del siglo xvi. Homenaje a Pedro Sáinz Rodriguez, III, Estudios Históricos, Madrid 1986.

2 García de Galarza convocó dos Sínodos. El primero en Cáceres el 11 de mayo de 1594, y el segundo en Coria el 9 de abril de 1595. De las Constituciones de 1594 se conserva una copia en la Biblioteca Pública del Estado en Cáceres, y las de 1595 están en el Leg. 82 del Archivo de la Catedral de Coria. Ambas ejercieron una notable influencia en las del Sínodo que convocó años más tarde su sucesor Pedro de Carvajal, y recogieron los principios contenidos en los Statuta Ecclesiae Cauriensis que García de Galarza elaboró probablemente en 1586, antes de la celebración de los interrogatorios que se analizan en este trabajo.

Véanse a este respecto M. A. ORti Y Belmonte: Episcopologio Cauriense. Cáceres 1959, pp. 106 a 121, y M. ${ }^{\mathrm{a}} \mathrm{J}$. Rodriguez Rodriguez: Sociedad y religión en Extremadura. Siglos xvı y xvII. Análisis sinodal de la diócesis de Coria. Cáceres 1980 (Memoria de Licenciatura inédita). 
las Constituciones Sinodales de 1537 y 1571, manifiestan la intención de conocer el nivel de instrucción doctrinal de los diocesanos, y aunque se descubre también la preocupación por conocer la moralidad de clérigos y laicos, ésta no es tan fundamental como la que prima en los objetivos del Obispo García de Galarza en 1591. La comparación de esta documentación con otras ${ }^{3}$ revela que después del Concilio de Trento, la Iglesia y sus principales instituciones - Inquisición, Colegios y Seminarios-, se esforzaron más por vigilar la moralidad de los fieles que por comunicarles dogmas y doctrinas.

Este trabajo, en homenaje al querido profesor Dr. Bethéncourt Massieu, sintetiza por primera vez todas las cuantificaciones a que da lugar el análisis sociológico de los 291 folios que componen parte del citado legajo 75 de Coria.

\section{LOS ACUSADORES}

Un total de 170 mujeres y 140 hombres declararon entre los días 4 y 28 de marzo de 1591 lo que sabian, o habían oído decir a otros, acerca del comportamiento moral de sus convecinos. Algunos de ellos repitieron su declaración. El siguiente cuadro sintetiza el desarrollo diario de las testificaciones.

3 J. Cobos Ruiz de AdANA: El clero en el siglo xvil. Estudio de una visita secreta a la ciudad de Córdoba. Córdoba 1976; M. ${ }^{a}$ A. Hernández Bermejo e I. Teston NúNez: Tiempo de Inquisición. La represión social en la Extremadura del siglo xvi. Hernán Cortés y su tiempo, I, Mérida 1987. 
Un proceso sin sentencia

DIA SEMANA

Martes

Miércoles

Jueves

Viernes

Sábado

Domingo

Lunes

Martes

Miércoles

Jueves

14

Viernes

Sábado

Lunes

Martes

Sábado

Jueves

23

28
2

9

20

18

44

38

19

29

45

14

17

31

23

15

4

3

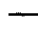

1
DECLARANTES

HOMBRES MUJERES 
La mayoría de las declaraciones se hicieron ante notarios y provisores nombrados por el Obispo; éste recibió el testimonio directo de 18 hombres y cuatro mujeres, entre los días 4 y 14 de marzo de 1591. A partir de esta última fecha el Obispo no volvió a recibir ningún testimonio, y parece probable que los que recibió fueron preparados de antemano, porque en la recepción de las declaraciones de las cuatro mujeres existen rasgos comunes que no pueden obedecer a la casualidad: se trata de cuatro criadas, analfabetas, que sirven a eclesiásticos de alto rango en la diócesis y a personas de relevancia en la vida social cauriense, solteras, y con edades comprendidas entre los 17 y 30 años; todas ellas prestaron declaración entre el viernes 8 y el lunes 11 de marzo, y las cuatro aseguraron haber visto lo que declaraban. Sus denuncias se refirieron a los mancebamientos episódicos y estables de altos cargos de la Iglesia cauriense, y -en declaraciones posteriores de otros testigosellas mismas aparecieron implicadas en los amancebamientos que denunciaron $y$ en el ejercicio de una prostitución que era demandada por quienes acusaban. El cuadro siguiente esquematiza el conjunto de rasgos comunes.

LAS CUATRO ÚNICAS MUJERES QUE DECLARARON ANTE EL OBISPO

\begin{tabular}{lllll}
\hline Nombres & María Alonso & Isabel Halcona & María Terrona & Catalina Hernández \\
Edades & 20 & 17 & 17 & 30 \\
Naturaleza & El Pedroso & Calzadilla & Coria & El Pedroso \\
Estado Civil & soltera & soltera & soltera & soltera \\
Profesión & criada & criada & criada & criada \\
Sabe leer & no & no & no & no \\
Expresiones & vio & vio & vio & vio \\
Acusaciones & & & a m a n c e b a m i e $n$ t o & \\
Acusados & Arcediano & Deán & Arcediano & Arcediano \\
& Clérigo & & Deán & Deán \\
& Deán & & Notario & Tesorero \\
& & & Pastelero & 3 clérigos \\
& & & Clérigo & Canónigo \\
& & & &
\end{tabular}


Todas estas criadas habian servido con anterioridad a algunas de las personas que acusaban; María Alonso había sido criada de Carmona, Arcediano de Valencia de Alcántara y en el momento de hacer su declaración lo era del Notario Alonso Gutiérrez de Paz, que será acusado de amancebamiento por otros testigos. Isabel Halcona había prestado sus servicios a amigos del Deán Herena, y fue acusada por otros testigos de haber mantenido relaciones con el mismo Deán. María Terrona, criada de Melchor de Salcedo, boticario, había asistido junto con Isabel Halcona, Marica de Paz, María la Reñala, y otras mujeres jóvenes a las reuniones que se celebraban en casa del Deán. Catalina Hernández servía a un clérigo, y había sido criada de otros tres, a los que acusa de amancebamiento con otras mujeres.

Probablemente el Obispo llamase a las cuatro mujeres porque supiera que estas testigos habian visto lo que iban a declarar, porque la mayoría de los acusadores utilizaron un léxico impreciso que casi no les comprometía porque sólo concretaban los nombres de los que acusaban, pero sin señaiar su observación directa. La mayoría de los testigos emplearon expresiones como "lo he oído decir», pero en muy contadas ocasiones señalan a quiénes. Sólo cuando el notario y el provisor insisten preguntando a quién se lo han oído, los testigos dan el nombre. Así, el comportamiento léxico de los declarantes permite establecer diferencias entre las expresiones utilizadas por los hombres y las mujeres, e incluso pueden distinguirse los comportamientos según la edad de los acusadores, su profesión, su nivel de instrucción, y el tipo de denuncia que hacen. Por regla general, y excepción hecha de las declaraciones de las cuatro criadas, quienes basan su testimonio en la observación directa, se refieren a las salidas nocturnas de algunos clérigos, a las prácticas y dichos que realizan curanderas y curanderos, y naturalmente quienes relatan apariciones de seres infernales. El cuadro siguiente sistematiza el léxico y el nivel de compromiso que tuvieron los acusadores. 
EL LÉXICO DE LA ACUSACION

\begin{tabular}{|c|c|c|c|c|c|}
\hline \multirow{2}{*}{ Expresiones } & \multirow{2}{*}{ N. ${ }^{\circ}$ declaraciones } & \multicolumn{2}{|c|}{ Hombres } & \multicolumn{2}{|c|}{ Mujeres } \\
\hline & & total & $\%$ & total & $\%$ \\
\hline lo oyó decir & 850 & 409 & 63 & 411 & 77 \\
\hline lo vio $\ldots .$. & 127 & 68 & 11 & 59 & 10 \\
\hline lo dijo $\ldots \ldots \ldots \ldots \ldots \ldots$ & 120 & 90 & 14 & 30 & 5 \\
\hline es público ...... & 87 & 55 & 8 & 32 & 6 \\
\hline lo sabe & 36 & 22 & 3 & 14 & 2 \\
\hline lo avisa & 5 & 5 & 1 & - & - \\
\hline TOTALES ........ & 1.225 & 649 & 100 & 576 & 100 \\
\hline
\end{tabular}

Como puede apreciarse, la mayor parte de los testigos hablan "de oídas", siendo el porcentaje de los que afirman su declaración - lo dijosuperior en los hombres. Algo semejante ocurre con el empleo de expresiones como "es público, lo sabe y to avisa".

Estos análisis, que permiten correlacionar variables distintas -sexo, edad, profesión, nivel de instrucción, léxico que emplean, acusaciones que hacen- ayudan a comprobar que el imperativo episcopal afectó de manera distinta a los acusadores: son los hombres de mayor edad y de mejor nivel de instrucción los que afirman más rotundamente su declaración. Las mujeres más jóvenes y las más adultas son las que ofrecen más detalles concretos, fijándose en aspectos como la ropa y sombrero que llevaban en cada momento las personas a las que acusaron, la hora aproximada a la que los vieron, la calle por la que andaban, y la casa donde les vieron entrar. La correlación de variables permite, asímismo, averiguar los móviles que motivaron los testimonios de algunos acusadores; quienes denuncian a adivinos y ensalmadores, lo hacen guiados por el afán de venganza, dado que tras haber pagado al adivino por el 
encargo de hallar un objeto perdido, o una res extraviada, no obtuvo el resultado apetecido. Los que acusan a curanderos lo hacen para defender a la persona que los curó, repitiendo la fórmula que emplearon e insistiendo en que nunca les oyeron solicitar el auxilio del demonio. Quienes denuncian a jugadores y a propietarios de tablajerías son asimismo jugadores, $y$ en otros testimonios aparecen como perdedores habituales. Pero donde mejor se observan algunas motivaciones es en los testigos que denuncian los amancebamientos; si se tienen en cuenta los días en que se hacen las acusaciones, es frecuente hallar al día siguiente de producirse un testimonio, otro que implica al testigo precedente acusándole del mismo delito que él denunció. Esta forma de defensa es practicada principalmente por los clérigos. El siguiente cuadro organiza los acusados que declararon como testigos y la interrelación de denuncias que producen. De un total de 48 testigos que a su vez fueron acusados por otros testimonios, 34 son hombres y 14 mujeres: en todas sus denuncias aparecen citados los testigos que les denunciaron.

ACUSADOS QUE DECLARARON COMO TESTIGOS

\begin{tabular}{|c|c|c|c|c|c|c|}
\hline NOMBRES & EDAD & PAOFESION & $\begin{array}{c}\text { DENUNC } \\
\text { HOMBRES }\end{array}$ & $\begin{array}{l}\text { DOS POR } \\
\text { MUJERES }\end{array}$ & $\begin{array}{c}\text { DENUU } \\
\text { HOMBRES }\end{array}$ & $\begin{array}{l}\text { CIAN A } \\
\text { MUJERES }\end{array}$ \\
\hline Alarcón, Jerónimo & 23 & criado & 1 & 3 & 10 & 9 \\
\hline Almaraz, Leonor & 45 & & 8 & 2 & 1 & 3 \\
\hline Alonso, Martín & 26 & receptor & 1 & - & 1 & - \\
\hline Bardales, Francisco & 30 & clérigo & 1 & 3 & 2 & 2 \\
\hline Basurta, Ana & 43 & ama & - & 1 & 7 & 7 \\
\hline Contreras, Francisco & 30 & & 1 & - & 12 & 2 \\
\hline Díaz, Antonia & 24 & & 1 & 1 & 3 & 3 \\
\hline Díaz, María & 27 & & 1 & - & 1 & 1 \\
\hline Erena, Juan B. & 19 & & - & 2 & 3 & 3 \\
\hline Estévez, Lorenzo & 40 & zapatero & 3 & 5 & 2 & 4 \\
\hline
\end{tabular}


ACUSADOS QUE DECLARARON COMO TESTIGOS

\begin{tabular}{|c|c|c|c|c|c|c|}
\hline NOMBRES & EDAD & PROFESION & $\begin{array}{c}\text { DENUNCI } \\
\text { HOMBRES }\end{array}$ & $\begin{array}{l}\text { DOS POR } \\
\text { MUJERES }\end{array}$ & $\begin{array}{c}\text { DENUN } \\
\text { HOMBREES }\end{array}$ & $\begin{array}{l}\text { IIAN A } \\
\text { MUJERES }\end{array}$ \\
\hline Gago & 44 & clérigo & 1 & 1 & 2 & 2 \\
\hline Gómez, Elvira & & & 13 & 8 & 1 & 1 \\
\hline Gómez, Isabel & 25 & & - & 1 & 2 & 2 \\
\hline Gómez, Juan & 33 & sastre & - & 1 & 1 & - \\
\hline Gómez, Martín & 44 & canónigo & 14 & 4 & 1 & 1 \\
\hline Italiano, Francisco & 38 & & 4 & 3 & 1 & 1 \\
\hline Jerez, Diego & 30 & clérigo & 4 & - & 11 & 9 \\
\hline Jiménez, Cristóbal & 53 & clérigo & 4 & 8 & 10 & 6 \\
\hline Jiménez, Juana & 25 & & 5 & 2 & 2 & 2 \\
\hline López, Ana & 30 & & - & 1 & 2 & 2 \\
\hline López, Ana & 20 & & - & 2 & 10 & 8 \\
\hline López, Rodrigo & & receptor & 17 & 6 & 15 & 11 \\
\hline Maestre, Francisco & 44 & herrador & 5 & 6 & 5 & 5 \\
\hline Martín, Benito & 42 & & - & 1 & 2 & 2 \\
\hline Martín, Jerónimo & 58 & muñidor & 8 & 13 & 4 & 1 \\
\hline Pereira, Francisco & & clérigo & 16 & 14 & 19 & 17 \\
\hline Pérez, Marcos & 38 & notario & 11 & 5 & 18 & 13 \\
\hline Pérez, Pedro & 66 & escribano & - & 1 & 7 & 6 \\
\hline Ponce de León, Juan & 34 & clérigo & 26 & 18 & 3 & 7 \\
\hline Porrina, Catalina & 30 & & - & 1 & 8 & 8 \\
\hline
\end{tabular}




\section{Un proceso sin sentencia}

ACUSADOS QUE DECLARARON COMO TESTIGOS

\begin{tabular}{|c|c|c|c|c|c|c|}
\hline NOMBRES & EDAO & PROFESION & \multicolumn{2}{|c|}{ DENUNCIADOS POR } & \multicolumn{2}{|c|}{ DENUNCIAN A } \\
\hline Quintana, Gonzalo & 24 & clérigo & 2 & - & 7 & 5 \\
\hline Ribera, Ana & & & 8 & 24 & 一 & - \\
\hline Rodriguez, Ana & 23 & & 3 & 4 & 5 & 5 \\
\hline Rodríguez, Juan & 34 & receptor & 19 & 13 & 5 & 4 \\
\hline Rodríguez, Maria & 40 & comadre & - & 1 & 6 & 7 \\
\hline Rosa, Isabel & 30 & & 1 & 2 & 4 & 4 \\
\hline Rubio, Diego & 48 & & 1 & - & 3 & 2 \\
\hline Salcedo, Melchor & 41 & boticario & 9 & 2 & 1 & 1 \\
\hline Salcedo, Juan & 28 & boticario & - & 1 & 4 & 一 \\
\hline Sánchez, Bartolomé & 30 & clérigo & 14 & 10 & 4 & 4 \\
\hline Sánchez, Francisco & 21 & herrero & 7 & 13 & 6 & 6 \\
\hline Sánchez, Juan & 38 & clérigo & 9 & 7 & 3 & 1 \\
\hline Sánchez, Pedro & 36 & ollero & 6 & 6 & 2 & 1 \\
\hline Simón, Juan & 28 & & 1 & 一 & 1 & 1 \\
\hline Torres, Bartolomé & 30 & escribano & 12 & 8 & 7 & 4 \\
\hline Torres, Pedro & 32 & & 4 & 7 & 4 & 4 \\
\hline Valverde, Diego & 26 & notario & 18 & 15 & 4 & 7 \\
\hline Villarreal, Juan & 27 & bachiller & 8 & 6 & 3 & 3 \\
\hline
\end{tabular}


La interrelación de los nombres de acusadores y acusados, la posterioridad de las fechas de declaración, junto con la repetición de algunos testimonios, permite suponer que el secreto debido a la recepción de las declaraciones y a la identidad de los testigos no debió de guardarse en más de una ocasión o fueron los mismos testigos los que divulgaron los contenidos de su declaración, o fueron los propios funcionarios episcopales, pero el hecho cierto fue que, salvo Ana Ribera que se presentó como testigo y no declaró nada y que a su vez había sido acusada por 32 testimonios, el resto de los acusados que hicieron declaraciones, denunciaron a sus acusadores.

¿Quiénes fueron los testigos? De los 140 hombres que se acercaron a declarar, sólo 45 señalaron no saber leer y hubo que leerles su declaración. Desconocemos la edad de ocho de los testigos, y sobre las 132 edades informadas, la edad media fue de 36 años y la modal, pese a la tendencia al redondeo, iguala a los varones de 30 y 40 años.

De las 170 mujeres que testificaron, sólo 15 manifestaron saber leer y firmar, y la edad media es de 31 años, siendo la modal de 40 años.

Conocemos también el estado civil de los testigos y una buena representación de sus profesiones. En el caso de las mujeres, no se cita el estado civil de 24 de ellas, siendo casadas 92 , solteras 37 y viudas 17. En el caso de los varones la información es más incompleta pues únicamente se cita directamente el estado civil de 41 de los 140 testigos, 31 son solteros, nueve casados y uno es viudo.

Ocurre lo contrario con la información sobre las profesiones de los varones, se informan 72 profesiones, mientras que de las mujeres sólo se citan 22 profesiones que en su mayoría son criadas.

El cuadro siguiente sintetiza toda la información sobre quiénes se presentaron a contestar el interrogatorio episcopal: 


\section{Un proceso sin sentencia}

RELACIÓN DE HOMBRES QUE COMPARECEN COMO TESTIGOS

\begin{tabular}{|c|c|c|c|c|}
\hline NOMBRES & EDAD & ESTADO CIVIL. & SABE LEER & PROFESIÓN \\
\hline Acosta, Antonio & 23 & soltero & sí & $\begin{array}{l}\text { familiar } S \text {. } \\
\text { Oficio }\end{array}$ \\
\hline Aguilar, Diego & & & sî & \\
\hline Alarcón, Jerónimo & 23 & soltero & sí & criado \\
\hline Almaraz, Francisco & 26 & & sí & \\
\hline Alonso, Martín & 26 & & sí & receptor \\
\hline Álvarez, Juan & 37 & & sí & zapatero \\
\hline Amarilla, Francisco & 52 & & sí & \\
\hline Amatiano, Martín & 40 & & sí & regidor \\
\hline Báez, Francisco & 17 & soltero & sí & \\
\hline Bardales, Francisco & 30 & soltero & sí & clérigo \\
\hline Barroso, Simón & +50 & & no & \\
\hline Bernal, Pedro & 40 & & sí & \\
\hline Blanco, Juan & 55 & casado & no & \\
\hline Blázquez, Pedro & 23 & & sí & tundidor \\
\hline Brozas, Diego & 20 & soltero & no & \\
\hline Cajas, Antonio & 29 & & sí & \\
\hline Cano, Luis & 24 & & no & \\
\hline Castro, Juan & 21 & & no & \\
\hline
\end{tabular}


Contreras, Francisco

Contreras, Francisco

Díaz, Francisco

Díaz, Tomé

Domínguez, Juan

Durán, Antonio

Erena, Juan B.

Estévez, Lorenzo

Flores, Antonio

Gago

Garay, Pedro

Garcia, Alonso

García, Juan

García, Juan

Garcia, Martín

García, Pedro

Gómez, Alonso

Gómez, Alonso

Gómez, Antonio
42

30

21 soltero

36

24

19

19 soltero

40

57

44 soltero

25

18 soltero

30 casado

35

40

35

30

23 sí regidor

sí

sí criado

sí platero

no cardador

sí estudiante

sí clérigo

no zapatero

sí bachiller

si clérigo

si receptor

sí

no labrador

no criado

sí

sí

no

no hortelano

sí escribiente 
RELACION DE HOMBRES QUE COMPARECEN COMO TESTIGOS

\begin{tabular}{|c|c|c|c|c|}
\hline NOMBRES & EDAD & ESTADO CIVIL & SABE LEER & PROFESIÓN \\
\hline Gómez, Juan & 40 & & no & \\
\hline Gómez, Juan & 33 & & sí & sastre \\
\hline Gómez, Martín & 44 & soltero & sí & canónigo \\
\hline Gómez, Pedro & 40 & & sí & alguacil \\
\hline Gómez de la Serna & 49 & & sí & \\
\hline González, Alonso & 30 & & no & \\
\hline Guillén, Pedro & 20 & & & \\
\hline Guinaldo, Pedro & 30 & & no & \\
\hline Gutiérrez, Antonio & 55 & & sí & joyero \\
\hline Gutiérrez, Hernán & 50 & casado & sí & procurador \\
\hline Gutiérrez, Juan & 30 & casado & no & \\
\hline Gutiérrez, Juan & 25 & casado & no & \\
\hline Gutiérrez, Juan & 36 & & sí & \\
\hline Gutiérrez, Juan & 20 & soltero & sí & criado \\
\hline Hernández, Gabriel & 45 & & no & \\
\hline Hernández, Juan & 28 & & no & \\
\hline Hernández, Lucas & 28 & & no & \\
\hline Italiano, Francisco & 38 & casado & no & lamparero \\
\hline Italiano, Francisco & 25 & casado & sí & \\
\hline
\end{tabular}


RELACION DE HOMBRES QUE COMPARECEN COMO TESTIGOS

\begin{tabular}{|c|c|c|c|c|}
\hline NOMBRES & EDAD & ESTADO CIVIL & SABE LEER & PROFESION \\
\hline Izquierdo, Francisco & 33 & & no & \\
\hline Jerez, Alonso & 40 & & sí & alguacil \\
\hline Jerez, Diego & 30 & soltero & sí & clérigo \\
\hline Jiménez, Cristóbal & 53 & soltero & sí & clérigo \\
\hline Lázaro, Francisco & 17 & soltero & sí & criado \\
\hline López, Diego & 38 & soltero & sí & clérigo \\
\hline López, Domingo & 27 & & no & \\
\hline López, Domingo & 46 & & no & \\
\hline López, Gaspar & 40 & casado & sí & zapatero \\
\hline López, Juan & 40 & casado & sí & cerrajero \\
\hline López, Martín & 55 & & no & \\
\hline López, Pedro & 16 & soltero & no & \\
\hline López, Pedro & +66 & & sí & \\
\hline López, Rodrigo & & & sí & notario \\
\hline Macías, Juan & 19 & soltero & sí & \\
\hline Maestre, Francisco & 44 & & no & herrador \\
\hline Marcos, Pedro & 60 & & no & \\
\hline Martín, Andrés & 21 & soltero & sí & \\
\hline Martín, Antón & 50 & & no & \\
\hline
\end{tabular}




\section{Un proceso sin sentencia}

RELACIÓN DE HOMBRES QUE COMPARECEN COMO TESTIGOS

NOMBRES

EDAD

ESTADO CIVIL

SABE LEER PROFESIÓN

Martín, Benito

Martín, Diego

Martín, Jerónimo

Martínez, Felipe

Martínez, Francisco

Mitata, Lucas

Morán, Juan

Moreno, Tomé

Moyano, Francisco

Muñoz, Diego

Navas, Andrés

Nieto, Juan

Orive, Cristóbal

Ortiz, Francisco

Páez, Juan

Pereira, Francisco

Pérez, Blas

Pérez, Marcos

Pérez, Pedro
42

36 soltero

50 casado

21 soltero

45

57

30

26

20

25

30

soltero

55

26

47

soltero

40

38

66 no

sí clérigo

no muñidor

sí

sí

sí

no

sí

sí criado

sí

sí

si clérigo

sí alguacil

sí

si sombrerero

sí clérigo

no hospitalero

sí notario

sí escribano 
RELACION DE HOMBRES QUE COMPARECEN COMO TESTIGOS

\begin{tabular}{|c|c|c|c|c|}
\hline NOMBRES & EDAD & ESTADO CIVIL & SABE LEER & PROFESIÓN \\
\hline Pérez, Roque & 32 & soltero & si & clérigo \\
\hline Ponce de León, Juan & 34 & soltero & sí & clérigo \\
\hline Ponce & 42 & & sí & licenciado \\
\hline Puente, Pedro & +40 & & sí & \\
\hline Quintana, Gonzalo & 24 & soltero & sí & clérigo \\
\hline Quintana, Hernando & 25 & & sí & \\
\hline Quirós, Pedro & 32 & & sí & \\
\hline Ramos, Domingo & 26 & & no & \\
\hline Rey, Alonso & 46 & & no & \\
\hline Robleja, Pedro & 45 & & sí & \\
\hline Rodríguez, Alonso & 52 & & no & sastre \\
\hline Rodríguez, Alonso & 40 & & no & calero \\
\hline Rodríguez, Diego & & & no & \\
\hline Rodriguez, Francisco & 19 & soltero & sí & \\
\hline Rodríguez, Francisco & 19 & & sí & \\
\hline Rodríguez, Juan & 34 & & sí & \\
\hline Rodríguez, Lorenzo & 44 & & sí & \\
\hline Rubio, Diego & 48 & & no & \\
\hline Salcedo, Juan & 28 & & sí & boticario \\
\hline
\end{tabular}


RELACION DE HOMBRES QUE COMPARECEN COMO TESTIGOS

\begin{tabular}{|c|c|c|c|c|}
\hline NOMBRES & EDAD & ESTADO CIVIL & SABE LEER & PROFESION \\
\hline Salcedo, Melchor & 41 & & sí & \\
\hline Salvador, Gonzalo & 76 & & sí & \\
\hline Sánchez, Alonso & 28 & & sí & \\
\hline Sánchez, Antón & 80 & & no & labrador \\
\hline Sánchez, Antonio & 40 & & si & barbero \\
\hline Sánchez, Bartolomé & 30 & soltero & si & clérigo \\
\hline Sánchez, Francisco & 21 & & no & herrero \\
\hline Sánchez, Francisco & 19 & soltero & no & criado \\
\hline Sánchez, Juan & 23 & & no & sastre \\
\hline Sánchez, Juan & 38 & soltero & sí & clérigo \\
\hline Sánchez, Pedro & +50 & & no & ollero \\
\hline Sánchez, Pedro & 36 & & no & \\
\hline Sierra, Gaspar & 55 & & sí & \\
\hline Simón, Juan & 28 & & no & \\
\hline Simón, Pedro & 28 & & sí & \\
\hline Sosa, Juan & 27 & soltero & sí & clérigo \\
\hline Soto, Gregorio & 36 & & sí & procurador \\
\hline Suárez, Francisco & +35 & & sí & procurador \\
\hline Torres, Bartolomé & 40 & & sí & escribano \\
\hline
\end{tabular}


RELACION DE HOMBRES QUE COMPARECEN COMO TESTIGOS

\begin{tabular}{lcccc}
\hline NOMBRES & EDAD & ESTADO CIVIL & SABE LEER & PROFESION \\
\hline Torre, Bartolomé & 30 & si & escribano \\
Torre, Francisco & 45 & sí & notario \\
Torre, Juan & 32 & sí & licenciado \\
Torre, Pedro & 26 & sí & \\
Valverde, Diego & & viudo & sí & receptor \\
Villanueva, Francisco & & sí & boticario \\
Villarreal, Amador & 55 & sí & \\
Villarreal, Juan & 27 & sí & bachiller \\
\hline
\end{tabular}

RELACION DE MUJERES QUE COMPARECEN COMO TESTIGOS

\begin{tabular}{lcccc} 
NOMBRES & EDAD & ESTADO CIVIL & SABE LEER & PROFESIÓN \\
\hline Aguilar, Inés & 40 & casada & no & \\
Aguilar, María & 30 & & no & \\
Alcona, Ana & 40 & & no & criada \\
Alcona, Isabel & 17 & soltera & no & sí \\
Almaraz, Leonor & 45 & viuda & no & \\
Alonso, Leonor & 22 & soltera & no & criada
\end{tabular}


RELACION DE MUJERES QUE COMPARECEN COMO TESTIGOS

ESTADO CIVIL

SABE LEER PROFESION

Alonso, María

Álvarez, Catalina

Álvarez, Isabel

Arias, Beatriz

Barrosa, Isabel

Basurta, Ana

Brozas, María

Cajas, Maria

Carrasco, Ana

Carrera, Ana

Carvajal, Francisca

Catalina

Catalina

Coria, María

Díaz, Antonia

Diaz, Catalina

Diaz, María

Durán, Teresa

Escobar, Ana

Flórez, Lucía
30 casada no

20 casada no

40 casada no

sí

23 casada no

43 no

40 casada no

40

si

viuda

no

16 soltera

no

50 viuda

no

39

no

30 casada no

24 casada no

24 soltera no

30 casada no

27 casada no

27 casada no

40 casada no

30 casada no 
RELACION DE MUJERES QUE COMPARECEN COMO TESTIGOS

\begin{tabular}{|c|c|c|c|c|}
\hline NOMBRES & EDAD & ESTADO CIVIL & SABE LEER & PROFESION \\
\hline Flórez, María & 40 & & no & \\
\hline García, Ana & 40 & casada & no & \\
\hline García, Isabel & 18 & soltera & no & criada \\
\hline García, Isabel & 25 & casada & no & \\
\hline Garcia, Maria & 24 & casada & no & \\
\hline García, María & 30 & viuda & no & \\
\hline Girón, Beatriz & 18 & soltera & sí & \\
\hline Girón, Isabel & 23 & casada & sí & \\
\hline Girón, Mariana & 27 & viuda & sí & \\
\hline Gómez, Catalina & 50 & casada & no & \\
\hline Gómez, Catalina & 30 & & no & panadera \\
\hline Gómez, Elvira & & casada & no & \\
\hline Gómez, Francisca & 26 & soltera & no & \\
\hline Gómez, Isabel & 25 & casada & no & \\
\hline Gómez, Juana & 30 & soltera & no & \\
\hline Gómez, Juana & 23 & soltera & no & criada \\
\hline Gómez, María & 30 & casada & no & \\
\hline González, Isabel & 18 & soltera & no & \\
\hline González, Isabel & 30 & soltera & no & \\
\hline González, María & 45 & casada & no & \\
\hline
\end{tabular}


RELACION DE MUJERES QUE COMPARECEN COMO TESTIGOS

\begin{tabular}{|c|c|c|c|c|}
\hline NOMBRES & EDAD & ESTADO CIVIL & SABE LEER & PROFESION \\
\hline Granada, Catalina & 20 & soltera & no & criada \\
\hline Gutiérrez, Ana & 20 & casada & no & \\
\hline Gutiérrez, Inés & 28 & & no & \\
\hline Gutiérrez, María & 25 & casada & si & \\
\hline Gutiérrez, María & 25 & casada & sí & \\
\hline Gutiérrez, Mencía & 24 & casada & no & \\
\hline Hernández, Ana & 22 & casada & no & \\
\hline Hernández, Catalina & 17 & soltera & no & criada \\
\hline Hernández, Catalina & 30 & soltera & no & criada \\
\hline Hernández, Catalina & 24 & casada & no & \\
\hline Hernández, Francisca & 28 & casada & no & \\
\hline Hernández, Juana & 40 & & no & \\
\hline Hernández, Juana & 40 & casada & no & \\
\hline Hernández, Maria & 17 & soltera & no & criada \\
\hline Hernández, María & 16 & casada & no & \\
\hline Hernández, María & 20 & casada & no & \\
\hline Hernández, Maria & 50 & viuda & no & \\
\hline Hernández, María & 20 & casada & no & \\
\hline Hernández, María & 40 & casada & no & \\
\hline Herrera, Maria & 14 & soltera & no & \\
\hline
\end{tabular}


RELACIÓN DE MUJERES QUE COMPARECEN COMO TESTIGOS

\begin{tabular}{|c|c|c|c|c|}
\hline NOMBRES & EDAD & ESTADO CIVIL & SABE LEER & PROFESION \\
\hline Herrera, Maria & 26 & casada & no & \\
\hline Jiménez, Isabel & 18 & soltera & no & criada \\
\hline Jiménez, Juana & 25 & casada & no & \\
\hline López, Ana & 20 & soltera & no & \\
\hline López, Ana & 30 & casada & no & \\
\hline López, Catalina & 34 & soltera & si & \\
\hline López, Francisca & 44 & & no & \\
\hline López, Jerónima & 24 & soltera & no & \\
\hline López, Juana & 34 & viuda & no & \\
\hline López, Juana & 40 & soltera & no & \\
\hline López, Lucía & 50 & & no & \\
\hline López, María & 30 & casada & no & \\
\hline López, Maria & 30 & soltera & no & criada \\
\hline López, Maria & 14 & soltera & no & \\
\hline Mariana & 22 & soltera & no & criada \\
\hline Martín, Ana & 14 & soltera & no & \\
\hline Martín, Ana & 40 & casada & no & \\
\hline Martin, Beatriz & 50 & viuda & no & \\
\hline Martín, Catalina & 26 & casada & no & \\
\hline Martín, Isabel & & casada & no & \\
\hline
\end{tabular}


RELACIÓN DE MUJERES QUE COMPARECEN COMO TESTIGOS

\begin{tabular}{|c|c|c|c|c|}
\hline NOMBRES & EDAO & ESTADO CIVIL & SABE LEER & PROFESION \\
\hline Martin, Isabel & 60 & casada & no & \\
\hline Martin, Isabel & 30 & viuda & no & \\
\hline Martín, María & 20 & casada & no & \\
\hline Mateos, María & 40 & casada & no & \\
\hline Micaela & 27 & casada & no & \\
\hline Miranda, Catalina & 50 & casada & no & \\
\hline Miranda, Luisa & 40 & casada & no & \\
\hline Montemayor, Ana & 23 & casada & no & \\
\hline Núñez, Isabel & 30 & soltera & sí & \\
\hline Núñez, María & 16 & soltera & no & \\
\hline Pérez, Catalina & 24 & casada & no & \\
\hline Pérez, Catalina & 21 & casada & no & \\
\hline Pérez, Isabel & +30 & casada & no & \\
\hline Pérez, Juana & 30 & casada & no & \\
\hline Pérez, Maria & 48 & viuda & no & \\
\hline Ponce, Ana & 28 & casada & sí & \\
\hline Ponce, Inés & 24 & casada & no & \\
\hline Prieta, Francisca & 43 & casada & no & \\
\hline Quebradas, Ana & 50 & casada & no & \\
\hline Ramirez, Mencía & 50 & & si & \\
\hline
\end{tabular}


RELACIÓN DE MUJERES QUE COMPARECEN COMO TESTIGOS

\begin{tabular}{|c|c|c|c|c|}
\hline NOMBRES & EDAD & ESTADO CIVIL & SABE LEER & PROFESIÓN \\
\hline Ramos, Catalina & 28 & casada & no & \\
\hline Resolia, Catalina & 45 & casada & no & \\
\hline Ribera, Ana & & & no & \\
\hline Rodríguez, Ana & 50 & viuda & no & \\
\hline Rodriguez, Ana & 50 & viuda & no & \\
\hline Rodríguez, Ana & 40 & casada & no & \\
\hline Rodríguez, Ana & 23 & casada & no & \\
\hline Rodríguez, Beatriz & & casada & no & \\
\hline Rodríguez, Catalina & 50 & & no & mesonera \\
\hline Rodríguez, Catalina & 18 & viuda & no & \\
\hline Rodríguez, Francisca & 60 & viuda & no & \\
\hline Rodríguez, Francisca & 44 & casada & no & \\
\hline Rodríguez, Francisca & 50 & & no & \\
\hline Rodríguez, Isabel & +50 & viuda & no & \\
\hline Rodríguez, Isabel & 25 & casada & no & \\
\hline Rodríguez, Juana & 19 & soltera & no & criada \\
\hline Rodríguez, Leonor & 21 & casada & no & \\
\hline Rodríguez, Leonor & +40 & & no & \\
\hline Rodríguez, Maria & 40 & soltera & no & criada \\
\hline
\end{tabular}


RELACION DE MUJERES QUE COMPARECEN COMO TESTIGOS

\begin{tabular}{|c|c|c|c|c|}
\hline NOMBRES & EDAD & ESTADO CIVIL & SABE LEER & PROFESIÓN \\
\hline Rodríguez, Maria & 19 & soltera & no & criada \\
\hline Rodríguez, María & 40 & casada & no & comadre \\
\hline Rodríguez, María & 25 & viuda & no & \\
\hline Rodríguez, María & 40 & casada & no & \\
\hline Rodríguez, María & 24 & soltera & no & \\
\hline Rodríguez, Marta & 30 & casada & no & \\
\hline Rodríguez, Úrsula & 20 & casada & no & \\
\hline Rosa, Isabel & 30 & & no & \\
\hline Salcedo, Isabel & 22 & casada & no & \\
\hline Salcedo, Leonor & 30 & casada & no & \\
\hline Salcedo, María & 38 & soltera & no & \\
\hline Salgada, Beatriz & 40 & soltera & no & \\
\hline Salgada, Francisca & 30 & viuda & no & \\
\hline Salgada, Luisa & 24 & soltera & no & \\
\hline Samaniego, Francisco & 17 & soltera & no & \\
\hline Sánchez, Ana & 40 & casada & no & \\
\hline Sánchez, Ana & 27 & casada & no & \\
\hline Sánchez, Catalina & 20 & soltera & no & criada \\
\hline Sánchez, Catalina & 20 & casada & no & \\
\hline
\end{tabular}




\section{RELACION DE MUJERES QUE COMPARECEN COMO TESTIGOS}

\begin{tabular}{|c|c|c|c|c|}
\hline NOMBRES & EDAD & ESTADO CIVIL & SABE LEER & PROFESION \\
\hline Sánchez, Catalina & 40 & casada & no & \\
\hline Sánchez, Catalina & 20 & casada & si & \\
\hline Sánchez, Catalina & 28 & casada & no & \\
\hline Sánchez, Francisca & 50 & & no & criada \\
\hline Sánchez, Francisca & 50 & casada & no & \\
\hline Sánchez, Isabel & 40 & casada & no & \\
\hline Sánchez, Isabel & 17 & soltera & no & criada \\
\hline Sánchez, Isabel & 19 & casada & no & \\
\hline Sánchez, Juana & 45 & casada & no & \\
\hline Sánchez, Lucía & +70 & & no & \\
\hline Sánchez, María & 50 & casada & no & \\
\hline Sánchez, María & 16 & casada & no & \\
\hline Sánchez, María & 40 & casada & no & \\
\hline Sánchez, Maria & 22 & casada & no & \\
\hline Sánchez, María & 28 & casada & no & \\
\hline Sánchez, María & 24 & casada & no & \\
\hline Sánchez, Teresa & 40 & casada & no & \\
\hline Santos, María & 16 & casada & no & \\
\hline Soria, Ana & 40 & casada & no & \\
\hline
\end{tabular}


RELACION DE MUJERES QUE COMPARECEN COMO TESTIGOS

\begin{tabular}{lccccc}
\hline NOMBRES & EDAO & ESTADO CIVL & SABE LEER & PROFESION \\
\hline Sosa, Beatriz & & casada & no & \\
Soto, María & 16 & soltera & no & \\
Talavera, Elvira & 30 & casada & si & criada \\
Terrona, Ana & 16 & soltera & no & no & criada \\
Terrona, María & 17 & soltera & si & \\
Villegas, Leonor & 33 & casada & & &
\end{tabular}

\section{LOS ACUSADOS}

Las declaraciones efectuadas por los testigos acusan a un total de 291 personas, de las que 36 son de difícil identificación por cuanto se las señala sin nombrarlas, y sin aportar datos suficientes que permitan su localización. De los 255 acusados, 35 son personalidades de la Iglesia Cauriense; por regla general, los testigos precisan la tipología de la inmoralidad que achacan a los acusados, aunque en ocasiones algunos testimonios generalizan la acusación contra el clero, "no dicen bien los artículos de la fe, andan con sobrepellices por la calle, no son diligentes en la administración de los sacramentos, no visitan a los enfermos", etc. Salvo esta excepción, las acusaciones se particularizan en hombres y mujeres, laicos y eclesiásticos, y puede sintetizarse en su cuantificación del modo siguiente. 
Amancebamiento

Relaciones sexuales episódicas

Alcahuetas

No hacer vida maridable

No estar velados

Blasfemia

Curanderos

Salir de noche

Juego

Adivinación

7

Como puede apreciarse, diez tipos de acusaciones particularizadas sintetizan el resultado final de un interrogatorio que descuida otras muchas cuestiones demandadas por el Obispo. Tanto las tipologias de las acusaciones, como el elevado número de amancebamientos denunciados, así como la repetición de 30 casos que incrementan la tipología de relaciones ilícitas, muestran una preocupación social que satisface probablemente la demanda institucional. En 1591 lo que llama la atención de los testigos es la ruptura de la formalidad; entrar en una casa ajena siendo de noche, volver del trabajo diario acompañado de una persona del sexo opuesto, aplazar la ceremonia de la velación, faltar de casa, atreverse a curar, apostar en el juego, ser sospechoso de favorecer unas relaciones amorosas, o invocar el nombre de Dios, o de sus más allegados, se convierten en infracciones que se admiten como tales por una sociedad 
que ha sido conducida de antemano por una dirección aceptada en el exclusivo nombre de la creencia popular. Esta atención que señala a la moralización entra en detalles que se convierten en delito en la óptica del denunciante: si el denunciado lleva su convivencia al extremo de compartir también su dinero, ropa y alimentos, el delito se considera mayor y nunca un ejemplo de solidaridad, ni de virtud. Lo que se condena con el rumor popular, o con la afirmación consciente de la denuncia, es la ruptura de las formas de convivencia dirigidas y consentidas: al adivino que no fracasa en su adivinación no se le denuncia, de la misma manera que lo que molesta a la conciencia social es quien vive teniendo hijos sin haber pasado previamente por el yugo y el mantón, que es lo que es la velación. Es la ruptura de los clichés lo que no se acepta por la sociedad, y probablemente el punto de observación más interesante sea el comportamiento público y oculto del clero. Los testigos acusan a 35 clérigos y dignidades eclesiásticas de llevar una mala vida que sólo se basa en el rumor y en la observación directa de testigos cuyas vidas también han de investigarse. El cuadro siguiente sistematiza las acusaciones que se lanzan contra el clero cauriense, y puede observarse que el comportamiento que se denuncia no es diferente del que se atribuye al resto de los denunciados.

\begin{tabular}{|c|c|c|}
\hline Alonso, Bartolomé ...... & clérigo & amancebamiento \\
\hline Bardales, Francisco ..... & clérigo, bachiller & amancebamiento. \\
\hline Barrientos, Pedro ........ & chantre & amancebamiento. \\
\hline Carvajal, Francisco .. & canónigo, juez sinodal & amancebamiento. \\
\hline Delgado & capellán, criado & $\begin{array}{l}\text { amancebamiento, sale de } \\
\text { noche. }\end{array}$ \\
\hline Díaz, Juan ... & clérigo, capellán & $\begin{array}{l}\text { amigado, empreñó a su } \\
\text { criada. }\end{array}$ \\
\hline Díaz, Pedro & clérigo, sacristán & amancebamiento. \\
\hline Durán. & clérigo & blasfemia. \\
\hline
\end{tabular}




\begin{tabular}{|c|c|c|}
\hline Herena, Alonso ........ & deán, doctor & $\begin{array}{l}\text { amancebamiento, sale de } \\
\text { noche, juega, trata. }\end{array}$ \\
\hline Gago $\ldots \ldots \ldots \ldots \ldots$ & cura, bachiller & amancebamiento. \\
\hline Garcia, Francisco ....... & clérigo & sale disfrazado. \\
\hline Gómez, Gaspar ........ & tesorero & $\begin{array}{l}\text { amancebamiento, sale de } \\
\text { noche, se disfraza, juega. }\end{array}$ \\
\hline Gómez, Juan ... & cura, beneficiado & $\begin{array}{l}\text { amancebamiento, sale de } \\
\text { noche, juega, granjea. }\end{array}$ \\
\hline Gómez, Martín & canónigo & amancebamiento. \\
\hline Gutiérrez, Gregorio & canónigo, doctor & amancebamiento, aborto. \\
\hline lbáñez, Diego . & arcediano & $\begin{array}{l}\text { amancebamiento, viola- } \\
\text { ción. }\end{array}$ \\
\hline Jerez, Diego . & clérigo, capellán & $\begin{array}{l}\text { juega, viste de seglar, } \\
\text { sale de noche. }\end{array}$ \\
\hline Jiménez, Cristóbal & clérigo, capellán & amancebamiento. \\
\hline Jiménez, Diego .. & clérigo & amancebamiento. \\
\hline Martín, Alonso ... & capellán & amancebamiento. \\
\hline Mesia, Lorenzo . & arcediano & juega, sale disfrazado \\
\hline Morales & beneficiado, bachiller & amancebamiento. \\
\hline Moreno, Juan .......... & cura, bachiller & amancebamiento. \\
\hline Pereira, Francisco & clérigo, capellán & $\begin{array}{l}\text { amancebamiento, curan- } \\
\text { dero. }\end{array}$ \\
\hline Pérez, Alonso & canónigo & sale de noche a mozas. \\
\hline
\end{tabular}




\begin{tabular}{|c|c|c|}
\hline Pérez, Diego ......... & racionero & amancebamiento. \\
\hline Ponce de León, Juan ... & beneficiado & $\begin{array}{l}\text { amancebamiento, alca- } \\
\text { huete, sale de noche. }\end{array}$ \\
\hline Quintana, Gonzalo . & capellán & $\begin{array}{l}\text { sale de noche, toca la } \\
\text { guitarra. }\end{array}$ \\
\hline Sánchez, Agustín & clérigo, criado & $\begin{array}{l}\text { ha empreñado una mu- } \\
\text { jer. }\end{array}$ \\
\hline Sánchez, Bartolomé & clérigo, criado & amancebamiento. \\
\hline Sánchez, Francisco ..... & clérigo & amancebamiento. \\
\hline Sánchez, Juan ......... & clérigo, capellán & $\begin{array}{l}\text { amancebamiento, viste de } \\
\text { seglar. }\end{array}$ \\
\hline Verdugo, Pedro ... & clérigo, racionero & amancebamiento. \\
\hline Villagutierre, Gaspar .... & canónigo, racionero & negocia. \\
\hline Villegas, Baltasar ....... & clérigo, organista & amancebamiento. \\
\hline
\end{tabular}

La relación estable y prohibida prima sobre otro tipo de acusaciones y delitos considerados graves por la Inquisición, apenas sí lo son desde la declaración de los testigos; las blasfemias no son tales, al menos la que se dijo pronunció el clérigo Durán, que no pasa de ser una expresión coloquial y vulgar. El jugar, o trabajar granjerías y negocios, no pasan de ser sino meras exageraciones elevadas a la categoría de delito por el testimonio social que saca del contexto verdadero el contenido de la denuncia. Todo parece remitir a un rumor que, aceptado socialmente e institucionalizado por el poder eclesial, vigila y quiere castigar: los clérigos atendidos por amas y criadas de edades jóvenes parecen suscitar la habladuría social y, aunque ha de aceptarse su testimonio, no se aportan los datos suficientes como para que el científico social pueda generalizar una situación de inmoralidad. 
Tal y como ha demostrado E. Morin, todavía en la actualidad el rumor y la consideración social de la inmoralidad despierta el afán de la generalización y una rapidez inusitada en la transmisión de este tipo de noticias. Pero todo ello no significa que la Iglesia no se empeñase en una cruzada contra la inmoralidad difundida fundamentalmente por el rumor; el afán de moralizar es un hecho constatable en los manuales educativos destinados a la juventud, y también en los manuales de confesores en las instrucciones que se destinan a regular la vida conventual, y en los estatutos y ordenanzas de colegios y seminarios. El tratamiento de los Mandamientos se nos aparece diferenciado, y un análisis cuantitativo de las preguntas que han de formular los confesores a los penitentes, demuestra que no es una casualidad el que el amancebamiento como relación estable, y la relación carnal episódica, sean los delitos más observados por la acusación social. Porque el muestreo sobre los 35 clérigos y dignidades eclesiásticas denunciadas, sólo revela 10 que es la generalidad de la denuncia social: las relaciones sexuales consideradas ilegales por la sociedad y por la Iglesia, constituyen la base más amplia de la acusación general, y ello no hace sino demostrar por dónde fue la pedagogía eclesiástica y la orientación de quien codificó el Edicto y las Cartas Generales del Obispo Garcia de Galarza.

El examen de un pequeño lugar de señorío facilita al Obispo construir una ordenanza sinodal que generaliza a toda la diócesis; la moralización requiere del asentimiento social basado en su propio nivel cultural, por ello quizás, la información dogmática y doctrinal se ve sustituida por la información moral, porque la respuesta social al interrogatorio no señala una deficiencia doctrinal sino moral, y como señalará un Obispo aragonés a mediados del siglo XVIII, es preferible que los párrocos en su predicación, insistan más sobre temas morales que doctrinales, porque la doctrina está más cerca de crear la duda, y la duda es la puerta por donde entran siempre el error y la herejía.

La mayor parte de los acusados son vecinos de Coria, excepción hecha de un clérigo de Hoyos, un zapatero portugués, un sastre norteafricano, el Arcediano de Valencia de Alcántara, el Arcediano de Cáceres, un par de moriscos, una viuda portuguesa, y un vecino de Hoyos, que es denunciado por amancebamiento con una mujer y con sus hijas.

El cuadro siguiente sintetiza el número de acusados, sus datos personales, y el delito del que se les acusa. 
RELACION DE ACUSADOS

NOMBRE

EDAD

E. CIVIL

PROFESION

DELITO

\begin{tabular}{|c|c|c|c|c|}
\hline Alarcón, Jerónimo & 23 & soltero & criado & amancebamiento. \\
\hline Almaraz, Leonor & 45 & viuda & & amancebamiento. \\
\hline Alonso, Bartolomé & & soltero & clérigo & amancebamiento. \\
\hline Alonso, Marina & & & ama & está preñada. \\
\hline Alonso, Martín & 26 & & receptor & conoce carnalmente. \\
\hline Amaca & & casado & & no está velado. \\
\hline Amarilla, Francisca & & casada & & conoce carnalmente. \\
\hline Arala, Juan & & soltero & & amancebamiento. \\
\hline Ávila, Luis & & casado & escribano & amancebamiento. \\
\hline Báez, Jorge & & & & anda con una casada \\
\hline Bardales, Francisco & 30 & soltero & clérigo & amancebamiento. \\
\hline Barrientos, Pedro & & soltero & chantre & amancebamiento. \\
\hline Basurta, Ana & 43 & soltera & ama & tiene un hijo. \\
\hline Blanco, Juan & & soltero & escribano & $\begin{array}{l}\text { tiene preñada una } \\
\text { moza. }\end{array}$ \\
\hline Brozas, Francisco & & & carcelero & $\begin{array}{l}\text { alcahuete, bigamo, adi- } \\
\text { vino. }\end{array}$ \\
\hline Cáceres, Juan & & & ollero & $\begin{array}{l}\text { conoce carnalmente a } \\
\text { una casada. }\end{array}$ \\
\hline Calero, Francisco & & soltero & criado & $\begin{array}{l}\text { conoce carnalmente a } \\
\text { una soltera. }\end{array}$ \\
\hline
\end{tabular}


RELACION DE ACUSADOS

\begin{tabular}{|c|c|c|c|c|}
\hline NOMBRE & EDAD & E. CIVIL & PROFESION & DELITO \\
\hline Cantos, Blas & & casado & & amancebamiento. \\
\hline Cantos, Juan & & & & amancebamiento. \\
\hline Carona, María & & casada & vendedora & amancebamiento. \\
\hline Carvajal, Catalina & & viuda & & amancebamiento. \\
\hline Carvajal, Francisco & & soltero & canónigo & amancebamiento. \\
\hline Castro, María & & & & amancebamiento. \\
\hline Cebollón, Francisco & & casado & & amancebamiento. \\
\hline Cigales, María & & casada & & $\begin{array}{l}\text { amancebada, está man- } \\
\text { tenida y ha parido. }\end{array}$ \\
\hline Contreras, Francisco & 30 & casado & & anda amigado. \\
\hline Contreras, Maria & & & criada & alcahueta. \\
\hline Contreras, Salvador & & & & amancebamiento. \\
\hline Coria, Francisca & & casada & & amancebamiento. \\
\hline Chinchilla & & & criado & curandero. \\
\hline Daza, Pedro & & & serviciador & $\begin{array}{l}\text { cópula carnal con una } \\
\text { casada. }\end{array}$ \\
\hline Delgado & & soltero & capellán & $\begin{array}{l}\text { amancebado, sale de } \\
\text { noche. }\end{array}$ \\
\hline Díaz, Alonso & & & regidor & $\begin{array}{l}\text { conoce carnalmente a } \\
\text { una casada. }\end{array}$ \\
\hline
\end{tabular}


RELACION DE ACUSADOS

\begin{tabular}{|c|c|c|c|c|}
\hline NOMBRE & EDAD & E. CIVIL & PROFESION & DELITO \\
\hline Díaz Nieto, Alonso & & & buldero & $\begin{array}{l}\text { amancebado, tiene hi- } \\
\text { jos. }\end{array}$ \\
\hline Díaz, Ana & & casada & & amancebamiento. \\
\hline Díaz, Antonia & & soltera & & $\begin{array}{l}\text { amancebada, ha pa- } \\
\text { rido. }\end{array}$ \\
\hline Diaz, Hernando & & casado & & $\begin{array}{l}\text { no hace vida marida- } \\
\text { ble. }\end{array}$ \\
\hline Diaz, Juan & & soltero & clérigo & $\begin{array}{l}\text { amigado con su criada, } \\
\text { la empreñó. }\end{array}$ \\
\hline Diaz, Maria & 27 & casada & & $\begin{array}{l}\text { recibe en su casa a } \\
\text { clérigos. }\end{array}$ \\
\hline Diaz, Pedro & & soltero & clérigo & $\begin{array}{l}\text { amancebado, tiene hi- } \\
\text { jos. }\end{array}$ \\
\hline Domínguez, Alonso & & casado & & $\begin{array}{l}\text { vive apartado de su } \\
\text { mujer. }\end{array}$ \\
\hline Dominguez, Maria & & soltera & criada & amancebamiento. \\
\hline Durán & & soltero & clérigo & blasfemia. \\
\hline Durán Madroño & & & & $\begin{array}{l}\text { ladrón, recibe mozas } \\
\text { en la cácel. }\end{array}$ \\
\hline Durán, Isabel & & viuda & labradora & $\begin{array}{l}\text { amancebada, ha pa- } \\
\text { rido. }\end{array}$ \\
\hline Erena, Alonso & & soltero & deán & $\begin{array}{l}\text { amancebado, juega, } \\
\text { sale de noche. }\end{array}$ \\
\hline Erena, Juan Bautista & 19 & soltero & & amancebamiento. \\
\hline
\end{tabular}


RELACIÓN DE ACUSADOS

\begin{tabular}{|c|c|c|c|c|}
\hline NOMBRE & EDAD & E. CIVIL & PROFESION & DELITO \\
\hline Estévez, Lorenzo & 40 & casado & zapatero & $\begin{array}{l}\text { amancebado, da mala } \\
\text { vida a su mujer. }\end{array}$ \\
\hline Figueroa & & & barbero & $\begin{array}{l}\text { entra en la cárcel a } \\
\text { acostarse con las pre- } \\
\text { sas. }\end{array}$ \\
\hline Flórez & & & sastre & conoce carnalmente. \\
\hline Flórez, Catalina & & casada & & $\begin{array}{l}\text { amancebada, ha pa- } \\
\text { rido. }\end{array}$ \\
\hline Frías, Diego & & & alguacil mayor & amancebamiento. \\
\hline Gago & 44 & soltero & cura & amancebamiento. \\
\hline Garcia, Alonso & & & notario & conoce carnaimente. \\
\hline García, Catalina & & & & conoce carnalmente. \\
\hline García, Elvira & . & viuda & & $\begin{array}{l}\text { amancebada, tiene opi- } \\
\text { niones religiosas equi- } \\
\text { vocadas. }\end{array}$ \\
\hline Garcia, Francisco & & soltero & clérigo & sale de noche. \\
\hline García, Francisco & & & tejedor & $\begin{array}{l}\text { trata con el diablo, en- } \\
\text { comienda. }\end{array}$ \\
\hline García, Luis & & casado & mercader & amancebado, juega. \\
\hline Garcia, Luisa & & soltera & & amancebamiento. \\
\hline García, Marisa & & & & curandera. \\
\hline Garcia, Salvador & & & sacristán & amancebamiento. \\
\hline
\end{tabular}


RELACION DE ACUSADOS

\begin{tabular}{|c|c|c|c|c|}
\hline NOMBRE & EDAD & E. CIVIL & PROFESIÓN & DELITO \\
\hline Gómez, Antonio & & soltero & escribiente & amancebamiento. \\
\hline Gómez, Catalina & & & & $\begin{array}{l}\text { trata a mala parte con } \\
\text { un cura. }\end{array}$ \\
\hline Gómez, Diego & & & labrador & $\begin{array}{l}\text { no va a misa, blas- } \\
\text { femo, consentidor. }\end{array}$ \\
\hline Gómez, Elvira & & casada & & amancebamiento. \\
\hline Gómez, Francisca & & casada & & cópula carnal. \\
\hline Gómez, Gaspar & & soltero & tesorero & $\begin{array}{l}\text { amancebado, juega, se } \\
\text { disfraza, sale de no- } \\
\text { che. }\end{array}$ \\
\hline Gómez, Hernán & & & cerrajero & $\begin{array}{l}\text { hace aparecer cosas } \\
\text { perdidas. }\end{array}$ \\
\hline Gómez, Isabel & & & ama & amancebada, parió. \\
\hline Gómez, Isabel & & & & alcahueta. \\
\hline Gómez, Isabel & 25 & casada & cestera & amancebamiento. \\
\hline Gómez, Isabel & & casada & & amancebamiento. \\
\hline Gómez, Isabel & & viuda & & amancebamiento. \\
\hline Gómez, Juan & 33 & & sastre & amancebamiento. \\
\hline Gómez, Juan & & soltero & cura & $\begin{array}{l}\text { amancebado, juega, } \\
\text { sale de noche, no im- } \\
\text { parte los sacramentos. }\end{array}$ \\
\hline Gómez Cebollón, Juan & & & & amancebamiento. \\
\hline
\end{tabular}


RELACION DE ACUSADOS

\begin{tabular}{|c|c|c|c|c|}
\hline NOMBRE & EDAD & E. CIVIL & PROFESION & DELITO \\
\hline Gómez Losada, Juan & & & recaudador & amancebado, juega. \\
\hline Gómez Mauricio, Juan & & soltero & bachiller & amancebamiento. \\
\hline Gómez, María & & casada & & amancebamiento. \\
\hline Gómez, Maria & & casada & & amancebamiento. \\
\hline Gómez, María & & soltera & criada & amancebamiento. \\
\hline Gómez, María & & viuda & & amancebamiento. \\
\hline Gómez, Maria & & casada & & $\begin{array}{l}\text { amancebada, les han } \\
\text { sorprendido. }\end{array}$ \\
\hline Gómez Herrera, María & & casada & & $\begin{array}{l}\text { amancebada, abando- } \\
\text { nada del marido. }\end{array}$ \\
\hline Gómez Muñoz, Martín & 44 & soltero & canónigo & amancebamiento. \\
\hline Gómez, Pedro & & & alguacil & amancebamiento. \\
\hline Gómez, Teresa & & viuda & & $\begin{array}{l}\text { amancebada, ha pa- } \\
\text { rido. }\end{array}$ \\
\hline González, Diego & & soltero & estudiante & $\begin{array}{l}\text { da dinero a una alca- } \\
\text { hueta. }\end{array}$ \\
\hline Granado, Bertol & & casado & & $\begin{array}{l}\text { anda a mala parte con } \\
\text { una casada. }\end{array}$ \\
\hline Gutiérrez, Ana & & casada & & amancebamiento. \\
\hline Gutiérrez, Antonio & & & & amancebamiento. \\
\hline Gutiérrez, Gregorio & & soltero & canónigo & $\begin{array}{l}\text { conoce carnalmente, } \\
\text { suministra abortivos. }\end{array}$ \\
\hline
\end{tabular}


RELACIÓN DE ACUSADOS

\begin{tabular}{|c|c|c|c|c|}
\hline NOMBRE & EDAD & E. CIVIL & PROFESION & DELITO \\
\hline Gutiérrez, Inés & & & & $\begin{array}{l}\text { amancebada, ha abor- } \\
\text { tado. }\end{array}$ \\
\hline Gutiérrez, Juan & & & sastre & amancebamiento. \\
\hline Guzmán, Beatriz & & casada & & $\begin{array}{l}\text { conoce carnalmente, } \\
\text { alcahueta. }\end{array}$ \\
\hline Hernández, Ana & & & & amancebamiento. \\
\hline Hernández, Ana & & casada & & amancebamiento. \\
\hline Hernández, Antonio & & casado & & $\begin{array}{l}\text { amancebado, da mala } \\
\text { vida a su mujer. }\end{array}$ \\
\hline Hernández, Catalina & & casada & & amancebamiento. \\
\hline Hernández, Diego & & & & vota a Dios. \\
\hline Hernández, Juan & & casado & & no está velado. \\
\hline Hernández, Maria & & & & $\begin{array}{l}\text { amancebada, alca- } \\
\text { hueta. }\end{array}$ \\
\hline Hernández, María & & viuda & & amancebamiento. \\
\hline Herrero, Juan & & casado & & no está velado. \\
\hline Ibáñez, Diego & & soltero & arcediano & $\begin{array}{l}\text { amancebado, ha vio- } \\
\text { lado una moza. }\end{array}$ \\
\hline Italiano, Francisco & 38 & casado & & amancebamiento. \\
\hline Jerez, Diego & 30 & soltero & clérigo & $\begin{array}{l}\text { viste de seglar, juega, } \\
\text { sale de noche. }\end{array}$ \\
\hline Jiménez, Ana & & casada & & amancebamiento. \\
\hline
\end{tabular}


RELACIÓN DE ACUSADOS

\begin{tabular}{|c|c|c|c|c|}
\hline NOMBRE & EDAD & E. CIVIL & PROFESION & DELITO \\
\hline Jiménez, Cristóbal & 53 & soltero & clérigo & amancebamiento. \\
\hline Jiménez, Diego & & soltero & clérigo & $\begin{array}{l}\text { trata a mala parte con } \\
\text { una casada. }\end{array}$ \\
\hline Jiménez, Juana & 25 & casada & & amancebamiento. \\
\hline Jiménez, María & & & ama & alcahueta. \\
\hline Juárez & & & procurador & vota a Dios. \\
\hline Leiva, Jerónimo & & & notario & anda amigado. \\
\hline Lezcano, Ana & & & & amancebamiento. \\
\hline Lezcano, Francisco & & & tendero & amancebamiento. \\
\hline Lobato, Juan & & casado & tabernero & amancebamiento. \\
\hline López, Ana & 30 & casada & & no hace vida maridable. \\
\hline López, Ana & & viuda & & amancebamiento. \\
\hline López, Ana & 20 & soltera & & amancebamiento. \\
\hline López, Ana & & casada & panadera & $\begin{array}{l}\text { amancebada, curan- } \\
\text { dera. }\end{array}$ \\
\hline López, Antonio & & casado & & no hace vida maridable. \\
\hline López, Elvira & & casada & & no hace vida maridable \\
\hline López, Francisca & & casada & & amancebamiento. \\
\hline López, Francisco & & casado & carnicero & amancebamiento. \\
\hline
\end{tabular}


RELACIÓN DE ACUSADOS

\begin{tabular}{|c|c|c|c|c|}
\hline NOMBRE & EDAD & E. CIVIL & PROFESION & DELITO \\
\hline López, Isabel & & viuda & & anda a mala parte. \\
\hline López, Isabel & & viuda & & $\begin{array}{l}\text { conoce carnalmente a } \\
\text { un huésped. }\end{array}$ \\
\hline López, María & & casada & & amancebamiento. \\
\hline López, Mateo & & soltero & & amancebamiento. \\
\hline López, Pedro & & casado & & no está velado. \\
\hline López, Rodrigo & & soltero & receptor & $\begin{array}{l}\text { amancebado, ha sido } \\
\text { sorprendido. }\end{array}$ \\
\hline Lozana & & casada & & conoce carnalmente. \\
\hline Madrigal, Francisco & & soltero & bordador & amancebamiento. \\
\hline Maestre, Francisco & 44 & casado & herrador & $\begin{array}{l}\text { amancebado, ha sido } \\
\text { sorprendido. }\end{array}$ \\
\hline Malreza, Francisco & & casado & & $\begin{array}{l}\text { no está velado, tiene un } \\
\text { hijo. }\end{array}$ \\
\hline Manzanedo, Luis & & & & amancebamiento. \\
\hline María, Juana & & casada & & $\begin{array}{l}\text { amancebada, ha sido } \\
\text { sorprendida. }\end{array}$ \\
\hline Martín, Alonso & & soltero & capellán & amancebamiento. \\
\hline Martín, Benito & 42 & & & consentidor \\
\hline Martín, Bernardino & & & labrador & trabaja en dias de fiesta. \\
\hline Martín, Domingo & & & carnicero & amancebamiento. \\
\hline
\end{tabular}


RELACIÓN DE ACUSADOS

\begin{tabular}{|c|c|c|c|c|}
\hline NOMBRE & EDAD & E. CIVIL & PROFESIÓN & DELITO \\
\hline Martín, Francisco & & & hortelano & amancebamiento. \\
\hline Martín, Francisco & & & & conoce carnalmente. \\
\hline Martín, Isabel & & & & $\begin{array}{l}\text { amancebada, alca- } \\
\text { hueta, encubridora. }\end{array}$ \\
\hline Martín, Jerónimo & 58 & casado & muñidor & curandero. \\
\hline Martín, Juan & & casado & trabajador & trabaja en dias de fiesta. \\
\hline Martín, Juan & & casado & & $\begin{array}{l}\text { hace aparecer las cosas } \\
\text { perdidas. }\end{array}$ \\
\hline Martín, Luis & & & & alcahuete. \\
\hline Martínez & & soltero & & amancebamiento. \\
\hline Mateos, Andrés & & & arriero & amancebamiento. \\
\hline Mendoza, Catalina & & & & amancebamiento. \\
\hline Mesia, Lorenzo & & soltero & arcediano & juega, sale de noche. \\
\hline Morales & & soltero & beneficiado & amancebamiento. \\
\hline Moreno, Francisco & & soltero & & vota a Dios. \\
\hline Moreno, Juan & & soltero & cura & amancebamiento. \\
\hline Ovando, Ana & & soltera & & amancebamiento. \\
\hline Ovando, Catalina & & soltera & & amancebamiento. \\
\hline Pantoja & & soltera & & ha tenido un hijo. \\
\hline
\end{tabular}




\begin{tabular}{|c|c|c|c|c|}
\hline NOMBRE & EDAD & E. CIVIL & PROFESIÓN & DELITO \\
\hline Pantrigo, Marcos & & casado & labrador & amencebamiento. \\
\hline Payo, Juan & & & & vota a Dios. \\
\hline Paz, Ana & & viuda & & amancebamiento. \\
\hline Paz, María & & soltera & criada & amancebamiento. \\
\hline Pedrero & & soltero & & alcahuete. \\
\hline Peña, María & & viuda & & amancebamiento. \\
\hline Pereira, Francisco & & soltero & clérigo & $\begin{array}{l}\text { amancebado, curan- } \\
\text { dero. }\end{array}$ \\
\hline Pereira & & viuda & & curandera. \\
\hline Pérez, Alonso & & soltero & canónigo & sale de noche a mozas. \\
\hline Pérez, Alonso & & & esgrimidor & $\begin{array}{l}\text { hace aparecer cosas } \\
\text { perdidas. }\end{array}$ \\
\hline Pérez, Ana & & & & amancebamiento. \\
\hline Pérez, Andrés & & viudo & ollero & $\begin{array}{l}\text { amancebado, hace apa- } \\
\text { recer cosas perdidas. }\end{array}$ \\
\hline Pérez, Diego & & soltero & racionero & amancebamiento. \\
\hline Pérez, Marcos & 38 & & notario & amancebamiento. \\
\hline Pérez, María & & & & amancebamiento. \\
\hline Pérez, María & & & & $\begin{array}{l}\text { frecuenta la casa de un } \\
\text { clérigo. }\end{array}$ \\
\hline
\end{tabular}




\begin{tabular}{|c|c|c|c|c|}
\hline NOMBRE & EDAD & E. CIVIL & PROFESION & DELITO \\
\hline Pérez, Pedro & 66 & & escribano & $\begin{array}{l}\text { hace en público opinio- } \\
\text { nes erróneas de Dios. }\end{array}$ \\
\hline Pimiento & & & botiller & conoce carnalmente. \\
\hline Ponce de León, Juan & 34 & soltero & clérigo & $\begin{array}{l}\text { amancebado, alca- } \\
\text { huete. }\end{array}$ \\
\hline Porrina, Catalina & 30 & casada & & amancebamiento. \\
\hline Pulida & & casada & & curandera. \\
\hline Quintana, Gonzalo & 24 & soltero & capellán & $\begin{array}{l}\text { sale de noche, toca la } \\
\text { guitarra. }\end{array}$ \\
\hline Rañala, María & & soltera & & $\begin{array}{l}\text { amancebada, alca- } \\
\text { hueta, encubridora. }\end{array}$ \\
\hline Redondo & & & & conoce carnalmente. \\
\hline Ribera, Ana & & soltera & & amancebamiento. \\
\hline Rodríguez, Ana & & casada & & amancebamiento. \\
\hline Rodriguez, Ana & 23 & casada & & conoce carnalmente. \\
\hline Rodríguez, Catalina & & soltera & criada & amancebamiento. \\
\hline Rodríguez, Diego & & casado & & amancebamiento. \\
\hline Rodríguez, Isabel & & casada & & $\begin{array}{l}\text { amancebada, no cree } \\
\text { en Dios. }\end{array}$ \\
\hline Rodríguez, Juan & 34 & casado & receptor & $\begin{array}{l}\text { amancebado, da mala } \\
\text { vida a su mujer. }\end{array}$ \\
\hline
\end{tabular}


RELACIÓN DE ACUSADOS

\begin{tabular}{|c|c|c|c|c|}
\hline NOMBRE & EDAD & E. CIVIL & PROFESION & DELITO \\
\hline Rodriguez, Leonor & & casada & & amancebamiento. \\
\hline Rodríguez, Lope & & soltero & & ha tenido un hijo. \\
\hline Rodríguez, María & & soltera & & $\begin{array}{l}\text { anda a mala parte con } \\
\text { un cura. }\end{array}$ \\
\hline Rodriguez, María & & & & $\begin{array}{l}\text { rapto y ocultación de un } \\
\text { niño. }\end{array}$ \\
\hline Rodríguez, María & 40 & casada & comadre & hechicera. \\
\hline Rodríguez, Pedro & & casado & & no hace vida maridable. \\
\hline Rocha & & soltero & criado & encomienda. \\
\hline Rosa, Isabel & 30 & casada & & $\begin{array}{l}\text { amancebada, alca- } \\
\text { hueta, busca hechice- } \\
\text { ras. }\end{array}$ \\
\hline Rubio, Diego & 40 & & & vota a Dios. \\
\hline Ruiz, Juan & & casado & tendero & amancebamiento. \\
\hline Ruiz Guadiana, Juan & & casado & notario & no está velado. \\
\hline Salcedo, Juan & 28 & casado & boticario & conoce carnalmente. \\
\hline Salcedo, Melchor & 41 & casado & boticario & amancebamiento. \\
\hline Sánchez, Agustín & & soltero & clérigo & empreñó a una criada. \\
\hline Sánchez, Bartolomé & 30 & soltero & clérigo & amancebamiento. \\
\hline
\end{tabular}


RELACIÓN DE ACUSADOS

\begin{tabular}{|c|c|c|c|c|}
\hline NOMBRE & EDAD & E. CIVIL & PROFESIÓN & DELITO \\
\hline Sánchez, Felipe & & & & vota a Dios. \\
\hline Sánchez, Francisca & & soltera & & amancebamiento. \\
\hline Sánchez, Francisco & & soltero & clérigo & amancebamiento. \\
\hline Sánchez, Francisco & 21 & casado & herrero & $\begin{array}{l}\text { amancebado, ha sido } \\
\text { sorprendido, da mala } \\
\text { vida a su mujer. }\end{array}$ \\
\hline Sánchez, Juan & 38 & soltero & clérigo & $\begin{array}{l}\text { amancebado, viste de } \\
\text { seglar. }\end{array}$ \\
\hline Sánchez, María & & casada & & amancebamiento. \\
\hline Sánchez, María & & viuda & & $\begin{array}{l}\text { amencebada, curan- } \\
\text { dera. }\end{array}$ \\
\hline Sánchez Corcha, María & & casada & & $\begin{array}{l}\text { amancebada, alca- } \\
\text { hueta. }\end{array}$ \\
\hline Sánchez Piquera, Maria & & viuda & & amancebamiento. \\
\hline Sánchez, Marina & & viuda & criada & $\begin{array}{l}\text { amancebada, está pre- } \\
\text { ñada. }\end{array}$ \\
\hline Sánchez, Pedro & 36 & soltero & ollero & amancebamiento. \\
\hline Simón, Juan & 28 & & & vota a Dios. \\
\hline Simona & & & panadera & amancebamiento. \\
\hline Soria, María & & casada & & alcahueta. \\
\hline Torre, Bartolomé & 30 & casado & escribano & $\begin{array}{l}\text { amancebado, ha sido } \\
\text { sorprendido, da mala } \\
\text { vida a su mujer. }\end{array}$ \\
\hline
\end{tabular}




\begin{tabular}{|c|c|c|c|c|}
\hline NOMBRE & EDAD & E. CIVIL & PROFESION & DELITO \\
\hline Torre, Felipe & 21 & soltero & & amancebamiento. \\
\hline Torre, Pedro & 32 & casado & & amancebamiento. \\
\hline Tripilla, Catalina & & soltera & criada & $\begin{array}{l}\text { amancebada, ha parido } \\
\text { un hijo. }\end{array}$ \\
\hline Valencia, María & & casada & & amancebamiento. \\
\hline Valverde, Diego & 26 & soltero & notario & $\begin{array}{l}\text { amancebado, ha sido } \\
\text { sorprendido. }\end{array}$ \\
\hline Vallejo, Francisco & & & & $\begin{array}{l}\text { amancebado, hace } \\
\text { cama redonda con las } \\
\text { hijas de la mujer con la } \\
\text { que vive. }\end{array}$ \\
\hline Vallés, Francisco & & & cerrajero & amancebamiento. \\
\hline Varela, Tomé & & casado & buhonero & $\begin{array}{l}\text { amancebado, riñe con } \\
\text { su mujer. }\end{array}$ \\
\hline Vega, Juan & & & albañil & consentidor. \\
\hline Vegas, Maria & & casada & & $\begin{array}{l}\text { reniega de haber reci- } \\
\text { bido el crisma. }\end{array}$ \\
\hline Velázquez, María & & & & $\begin{array}{l}\text { amancebada, alca- } \\
\text { hueta. }\end{array}$ \\
\hline Verdugo, Pedro & & soltero & clérigo & amancebamiento. \\
\hline Villagutierre, Gaspar & & soltero & canónigo & anda en negocios. \\
\hline Villarreal, Juan & 27 & casado & & $\begin{array}{l}\text { amancebado, da mala } \\
\text { vida a su mujer. }\end{array}$ \\
\hline
\end{tabular}


RELACIÓN DE ACUSADOS

\begin{tabular}{|c|c|c|c|c|}
\hline NOMBRE & EDAD & E. CIVIL & PROFESION & DELITO \\
\hline Villegas, Baltasar & & soltero & clérigo & amancebamiento. \\
\hline Vinagra, Catalina & & casada & & amancebamiento. \\
\hline Xinés, Luisa & & casada & & amancebamiento. \\
\hline Zayas, Antonio & & & & vota a Dios. \\
\hline Zayas, Maria & & & & $\begin{array}{l}\text { llama a mozas para que } \\
\text { tengan acceso carnal } \\
\text { con su hermano, fraile } \\
\text { francisco. }\end{array}$ \\
\hline Catalina & & casada & & amancebamiento. \\
\hline Ana & & & criada & amancebamiento. \\
\hline Antonio & & & criado & amancebamiento. \\
\hline Alonso & & casado & & no hace vida maridable. \\
\hline Una & & & esclava & alcahueta. \\
\hline Un & & casado & & no está velado. \\
\hline Sebastián & & casado & tendero & $\begin{array}{l}\text { amancebado, da mala } \\
\text { vida a su mujer. }\end{array}$ \\
\hline Una & & casada & & curandera. \\
\hline María & & soltera & criada & alcahueta. \\
\hline Martín & & & criado & amancebamiento. \\
\hline Garcia & & casada & & curandera. \\
\hline
\end{tabular}


RELACION DE ACUSADOS

\begin{tabular}{llll}
\hline NOMBRE & EDAD E. CIVIL & PROFESION & DELITO \\
\hline Domingo & criado & trabaja en dias de fiesta. \\
Un & cantor & $\begin{array}{l}\text { amancebado, ha sido } \\
\text { sorprendido. }\end{array}$ \\
Un & maestro de & $\begin{array}{l}\text { amancebamiento. } \\
\text { Capilla }\end{array}$ \\
mastrescuela & $\begin{array}{l}\text { anduvo detrás de una } \\
\text { casada. }\end{array}$ \\
\hline
\end{tabular}

La sintesis de acusados y de acusaciones permite diferenciar tipologías de delitos, algunos de los cuales deberían haber ido a un tribunal inquisitorial. La muestra que constituye el Legajo 75 de la Catedral de Coria es suficientemente representativa de lo que fue el predominio de lo moral sobre lo doctrinal. La terminación del interrogatorio sin sentencia y la inmediata convocatoria del Sinodo, significan que lo que verdaderamente importaba al Obispo García de Galarza era la información, para inspirar la redacción de unos cánones sinodales, y con ellos toda su actividad pastoral posterior. 